の特集 : 人工膜と生体膜の接点をさぐる

生体膜のイオンチャネルの構造と機能

高桑雄 一

東京女子医科大学 生化学教室 焉 186 東京都新宿区河田町 8-1

\title{
Structure and Function of Ion Channels
}

\author{
Yuichi Takakuwa, M. D., Ph. D. \\ Department of Biochemistry Tokyo Women's Medical College \\ 8-1 Kawada-cho, Shinjyuku-ku, Tokyo 162, Japan
}

\begin{abstract}
The hydrophobic environment of the lipid membrane bilayer is virtually impermeable to ions in aqueous solution. Protein channels permit the rapid flux of ions across membranes. Ion channels have a common structural motif, the transmembrane $\alpha$-helix. In its most energetically favorable form the protein must be configured such that its most hydrophilic residues point toward the aqueous channel and its hydrophobic residues face the lipid bilayer. Voltage-gated ion channel for $\mathrm{Na}^{+}$is constracted from a single large polypeptide chain. The polypeptide includes four internally homologous domains I - IV, each containing six hydrophobic membrane-spanning regions, S 1 - S 6 , that probably correspond to $\alpha$-helices. These four interconnected domains are thought to arrange as a tetramer surrounding the voltage-gated ion channel. S 4 is thought to fuction as the actual voltage sensor of depolarization that causes a conformational change to open the channel pore. A small pore size and the biochemistry of the pore lining conspire to determine the ion selectivity of a particular type of channel.
\end{abstract}

Key words : ion channel, $\alpha$-helix, $\mathrm{Na}^{+}$channel, voltage sensor, ion selectivity

\section{1.はじめに}

生体内ではイオンは一般に水和している．例え ば, $\mathrm{Na}^{+}, \mathrm{K}^{+}$などの陽イオンは水分子の酸素原 子と静電気的に結合し, 周囲に水の殻を持った状 態となり，サイズも大きくなる．これらの水和イ オンは脂質二重層を基本構造とする疎水性環境の 細胞膜を単純には透過できない (Fig. 1). しかる に細胞内外のイオン組成および濃度には大きな差 がある，例えば, $\mathrm{Na}^{+}$濃度は細胞内より細胞外 で高く, $\mathrm{K}^{+}$はその逆である. また, $\mathrm{Ca}^{2+} に い$
たっては, 細胞内 $\left(10^{-7} \mathrm{M}\right)$ は細胞外 $\left(10^{-3} \mathrm{M}\right)$ の 1 万分の 1 に低く保たれている. これらの濃度 勾配は膜を貫通している種々のイオンポンプ (ATPase) によるイオンの能動輸送によって維 持されており, その結果, 膜を挟んで電気化学ポ テンシャル electrochemical potential が生ず る(Fig. 2). 細胞膜にはそれぞれのイオンに特有 のチャネルがあり, それぞれのイオンの作る電気 化学ポテンシャルを駆動力として, 高濃度側から 低濃度側へ受動的にイオンを通過させることがで きる.これらのイオンチャネルは静止状態では閉 
じており，刺激によって開きイオンを速やかに透 過させる装置とみなせる. したがって, 生体内で このイオン電流は，一般的に細胞外からの刺激や 情報を細胞内に伝える有効な手段となり, 神経や 筋肉では電気的興奮を惹起する。. また, 細胞内の $\mathrm{Ca}^{2+}$ 増加は二次伝達物質として様々な生理機能 を引き出す。

この総説では, 生体膜におけるイオンチャネル の構造とイオン透過機構について, 主に $\mathrm{Na}^{+}$チャ ネルを例に解説し, 人工膜に再現可能であるか否 かを含めて人工膜との接点をさぐることにする. なお，イオンチャネルの構造とイオン透過機構に 関する他の成書も参照されたい ${ }^{1 \sim 5)}$.

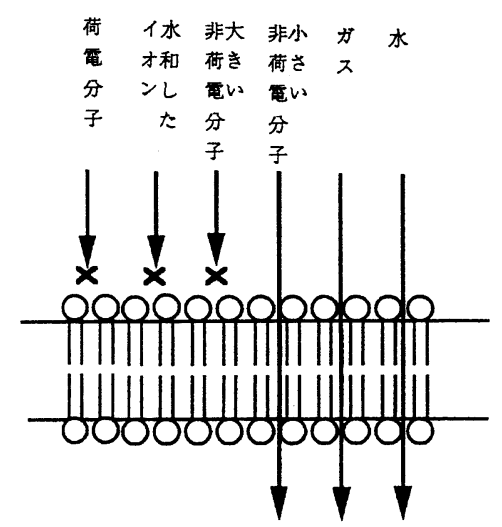

Fig. 1 Permeability of molecules across the biological membranes.

\section{2. イオンチャネルの構造}

脂質二重層を基本構造とする生体膜の内部は疎 水性環境亡なっている. イオンチャネルの実体は 膜貫通蛋白であり, イオンを透過させるチャネル 内面は親水性で, 脂質と接する外面は疎水性でな ければならない，一般に，蛋白はアミノ酸がペプ チド結合により連結したポリペプチドで, $\mathrm{C}=\mathrm{O}^{-}$, $\mathrm{N}-\mathrm{H}^{+}$部分は親水性であり, 各アミノ酸 (20 種 類）の側鎖には疎水性のもの（ロイシン Leuな ど）もあるが，親水性のもの（セリン Ser など） もある. したがってポリペプチド鎖を単にまっす ぐ伸ばした場合は，疎水性の環境には存在できな い (Fig. 3). しかし, 膜貫通蛋白は $\alpha$-helix 構造 をとっており, $\mathrm{C}=\mathrm{O}^{-}, \mathrm{N}-\mathrm{H}^{+}$間には水素結合が 生じ, この部分の親水性は失われている(Fig. 4). 実験的に親水性側鎖をもつセリンと, 疎水性 側鎖をもつロイシンの合成ペプチドからなる $\alpha$-helixを用いた場合, $6 つ の ~ \alpha$-helix が集まり， 内面に親水性のセリンからなる孔を形成し，膜脂 質と接する外面に疎水性のロイシンが配置するこ とによって脂質二重層を貫いて存在できる (Fig. 5).生体における実際のイオンチャネルもいくつ かの $\alpha$-helix が集まっており，イオンが通過する 内面の孔（チャネル）は親水性アミノ酸で構成さ れている. 複数のポリペプチド鎖の $\alpha$-helix から なる場合（アセチルコリン受容体など）と，1 本
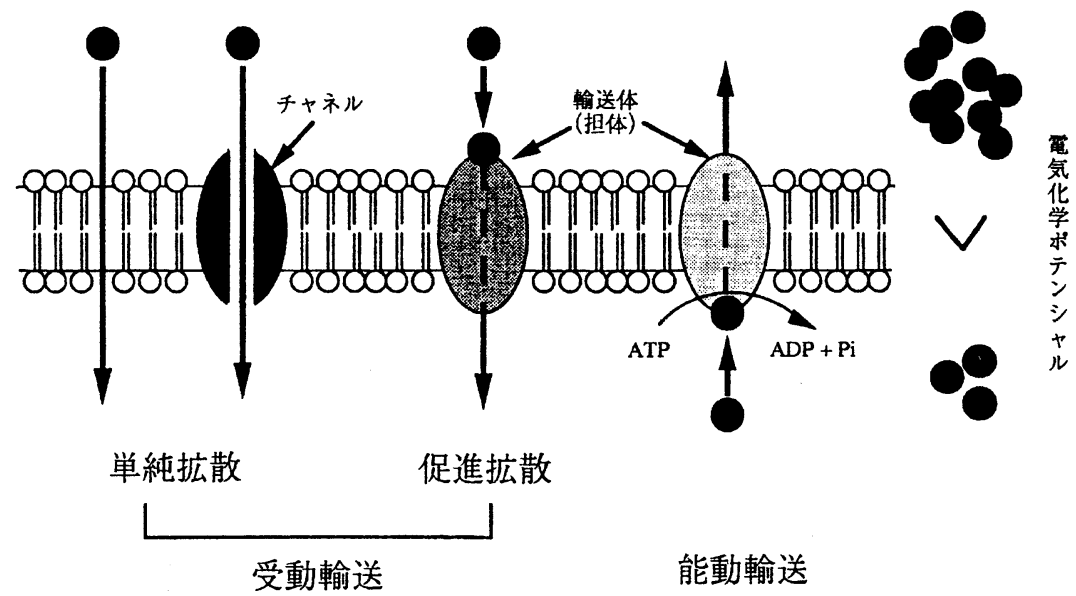

\section{能動輸送}

Fig. 2 Passive and active transports across the biological membranes. 
のポリペプチド鎖が複数の $\alpha$-helix をもつ場合 ( $\mathrm{Na}^{+}$チャネルなど) がある. 本総説では, $\mathrm{Na}^{+}$ チャネルを例にアミノ酸配列, センサー, フィル ター,ゲート機構について説明する.

\section{3. $\mathrm{Na}^{+}$チャネルの構造}

1984 年, 沼らによって, 遺伝子組み換え技術 を用いて, 電気ウナギ発電器官の $\mathrm{Na}^{+}$チャネル の 1820 のアミノ酸配列が明らかになった ${ }^{6)}$ 。こ の二次構造について 5 つの構造上の特徴が挙げら

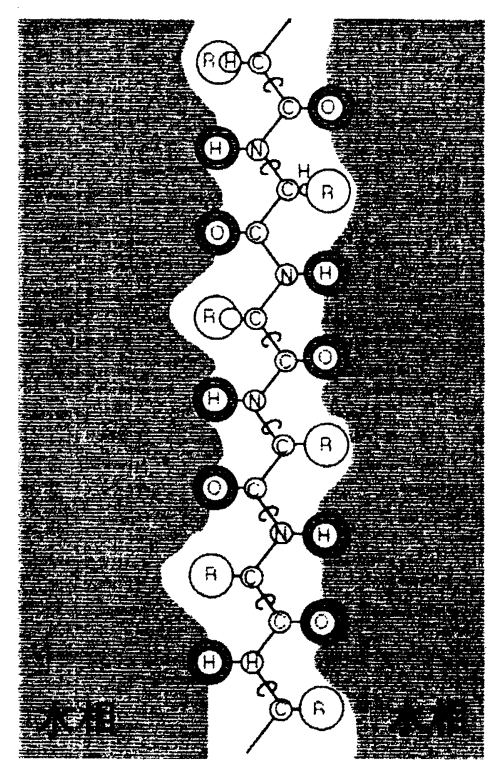

Fig. 3 Structure of a peptide chain in the aqueous phase.
れる $\left(\right.$ Fig. 6) ${ }^{7)}$.第 1 は, 分子内に相同性の高い 4つの繰り返し構造（ドメイン 1 4）をもつこと であり，第 2 は，各ドメインが $6 \supset$ つグメント (S 1 S 6) に分けられることである. それぞれ のセグメントは約 20 の疎水性アミノ酸に富む $\alpha$-helix 構造をとり, 脂質二重層を貫通している. $\alpha$-helix におけるアミノ酸 1 残基の長軸方向の長 さは平均 $0.15 \mathrm{~nm}$ であり, 20 アミノ酸で生体膜 の厚さ（約 $3 \mathrm{~nm}$ ）に相当する. 第 3 は, S 2 に は正と負の, S 1 と S 3 には負の電荷が存在し, 親水性のイオン通過孔を形成すると考えられる.

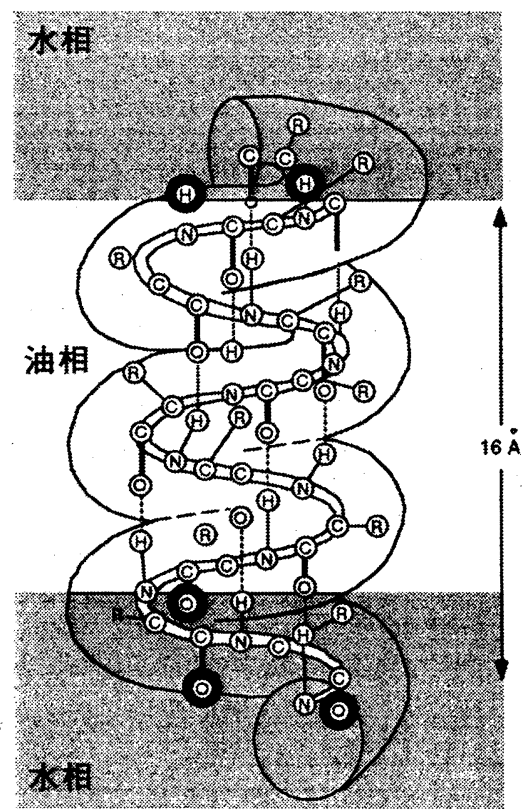

Fig. 4 Structure of $\alpha$-helix in the lipid phase.

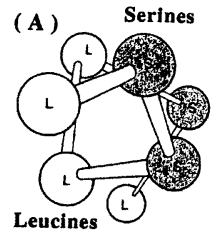

(B)

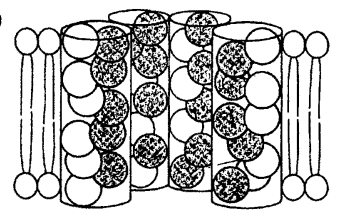

(C)

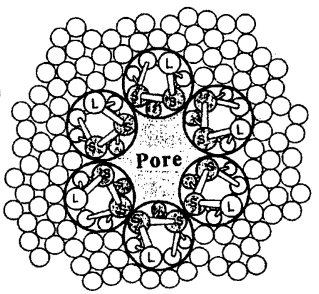

Fig. 5 Prototypical ion channel constructed experimentally from transmembrane $\alpha$-helical domain.

A. a peptide containing only serine and leucine residues.

B. formation of an ion channel by $\alpha$-helices.

C. a view through the channel. (from Text book ${ }^{1)}$ ) 


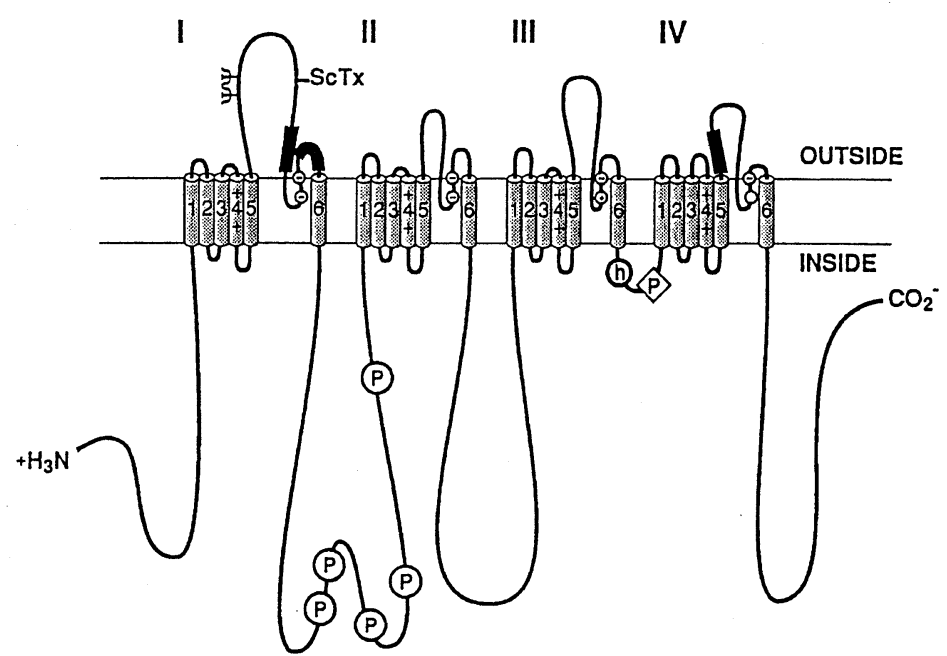

Fig. 6 Model for the secondary structure of voltage sensitive $\mathrm{Na}^{+}$channel. (from Review ${ }^{7)}$ )
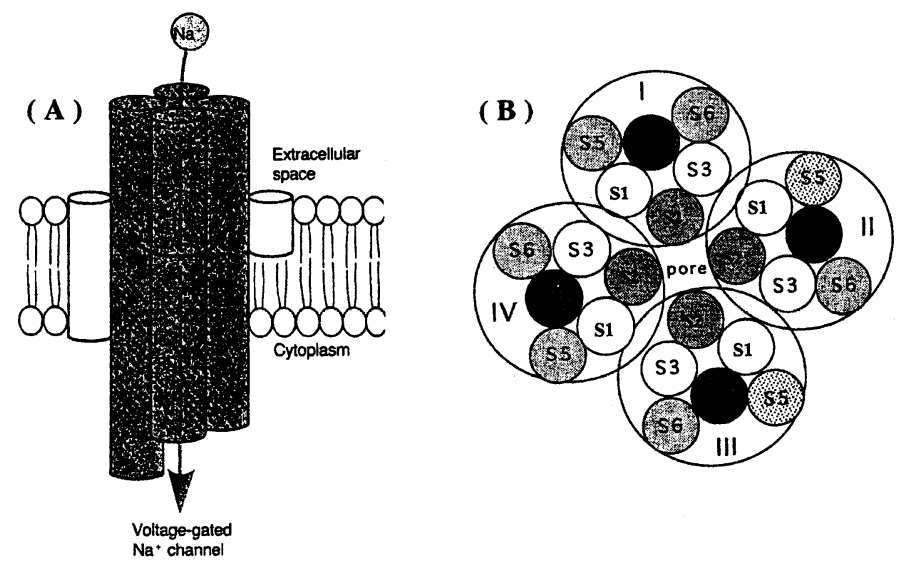

Fig. 7 Model for the channel-forming polypeptides.

A. schematic view.

B. a view through the channel.

第 4 に, S 4 は構成アミノ酸の $1 / 3$ が正電荷をも つアルギニン Arg やリジン Lys で占められ，こ れらが 3 残基毎に規則正しく配置されている. ゲート機構に関連すると予想されている（後述）. 第 5 に, S 5 と S 6 は完全な疎水性の $\alpha$-helix で チャネル外周に位置する. 結局, これら 6 つのセ グメントからなる束(ドメイン)が 4 つ集まって, 中心にひとつのチャネルが形成され，その内面は 4 つの S 2 からなっている (Fig. 7).このような 基本構造は, 他の電位依存性イオンチャネル
$\left(\mathrm{Ca}^{2+}\right.$ チャネルや $\mathrm{K}^{+}$チャネル $)$にも存在するこ とから,これらは共通の原型遺伝子に由来してい ると推定される.

\section{4. イオン透過機構}

イオンチャネルを介するイオン輸送は, 細胞膜 内外のイオン濃度差によって生ずる電気化学ポテ ンシャルに従う受動輸送である. したがって, イ オンチャネルにはその特性を規定する 3 つの要素 
がある.すなわち，チャネルの開閉状態を作り出 すゲート, 透過するイオンの選択性, イオンの通 りやすさを規定するチャネル内部のポテンシャル エネルギー場が重要である.

\section{1 ゲート機構}

チャネルの開閉はチャネル蛋白の高次構造の変 化によるゲート機構で説明される.刺激としては, 電気的興奮と化学的興奮があり, $\mathrm{Na}^{+}$チャネル などの電位作働性チャネルは, 脱分極によりゲー トが開く.静止状態では細胞内が負電位であり, S

\section{(A) LGAIKSL $\stackrel{+}{R T L} \stackrel{+}{\mathrm{RALR}_{\mathrm{R}}} \stackrel{+}{\operatorname{R}} \stackrel{+}{\mathrm{R}} \mathrm{ALSR} \stackrel{+}{\mathrm{R} F}$}

(B)

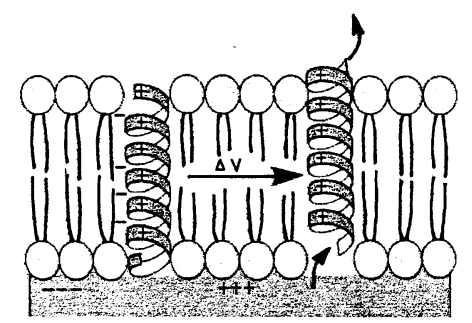

(C)

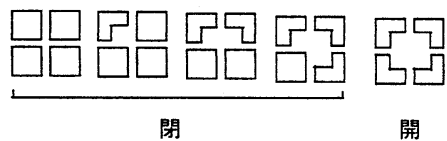

Fig. 8 Model for the action of the $\mathrm{S} 4$ resion voltage sensor.

A. amino acid sequence of the $\mathrm{S} 4$ helix.

B. axial and outword rotaion of the S 4 helix on depolarization.

C. conformational change of four domains to open the channel pore.

(A)

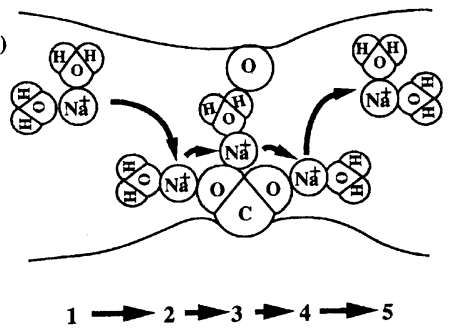

4 セグメントの 3 つおきに並ぶ 6 個の正電荷は, 隣接する他のセグメントの負電荷とつり合ってい るが, 脱分極によって細胞膜外側の電位が負にな ると, 電気的な力でこれら正電荷は外側に引っ張 られる. その結果, S 4 の $\alpha$-helix は 60 度ねじれ る小さな変化でイオン対が 1 個ずれ，全体として 膜の内側から外側へ正電荷が 1 個移動したことに なる.この構造変化が 4 つのドメインの S 4 すべ てに起こってはじめてイオン透過孔が開く (Fig. 8). $\mathrm{Na}^{+}$チャネルの不活性化はこの逆過程である が，実際には予想されるより遥かに速やかに不活 性化されることから, 不活性化ゲートが別に存在 すると考えられている．ドメイン 3 と 4 を結ぶ短 い細胞質部分の関与が強く示唆されているが，明 確なモデルはまだない.

\section{2 イオン選択機構}

それぞれのイオンチャネルは特定のイオンを選 択的に透過させるフィルターの役割を果してい る. 例えば $\mathrm{Na}^{+}$チャネルは $\mathrm{Na}^{+}$のみを透過させ， $\mathrm{K}^{+}$や $\mathrm{Ca}^{2+}$ など他のイオンはほとんど透過でき ない，この選択性はチャネル孔径とイオン（水和 イオン)サイズの大小関係で説明できる例もある. 例えば, $\mathrm{Na}^{+}$チャネルの最小孔径より大きな径 をもつ $\mathrm{Ca}^{2+}$ は $\mathrm{Na}^{+}$チャネルを透過できない. しかし，大きさの比較のみでは $\mathrm{Na}^{+}$チャネルの 最小孔径より小さな径の $\mathrm{K}^{+}$が $\mathrm{Na}^{+}$チャネルを 透過できない理由を説明できない。したがって， イオン選択機構はチャネル孔を構成するアミノ酸 の立体配置, 電荷, 電場とイオンの相互作用と考

Fig. 9 Model of a selectivity filter in the $\mathrm{Na}^{+}$channel.

A. $\mathrm{Na}^{+}$movement at a proposed narrowing along the channel wall

B. diagram of energy barrier at the inlet. 

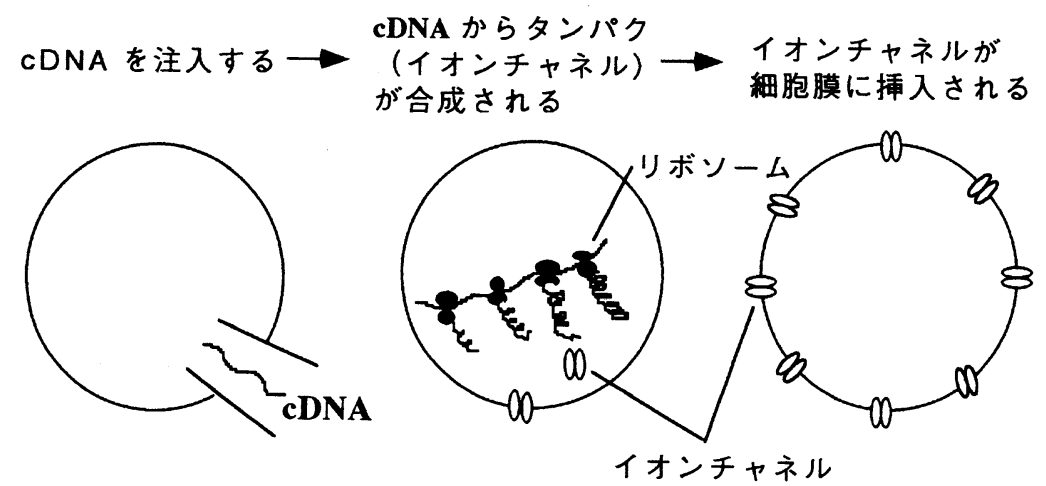

\section{カエル卵母細胞}

Fig. 10 Expression of ion channel in a Xenopus oocyte.

えるべきである.

$\mathrm{Na}^{+}$が $\mathrm{Na}^{+}$チャネルのフィルター部を通過す る過程と，それに対応するエネルギー障壁のダイ アグラムが提唱されている (Fig. 9).フィルター 部分は少なくとも 1 個のカルボキシル基と複数個 の酸素原子（セリンなど）で構成され, $\mathrm{Na}^{+}$は カルボキシル基の電場の強い脱分極時に水和イオ ンとして透過する.この際, 最大エネルギー障壁 （Fig. 9 B の 3 の位置）を超えることになる. $\mathrm{K}^{+}$ はカルボキシル基と相互作用する距離が $\mathrm{Na}^{+}$に 比べてイオン半径の差 $(0.38 \AA)$ だけ遠いため, 最大エネルギー障壁はより高くなり, 選択性はよ り低くなる，また，チャネル内部にポテンシャル エネルギー場があることによって，チャネル全体 の電位に勾配が生じ, 順次エネルギー障壁を超え イオン透過の方向性が決定されると考えられてい る.

以上, 生体膜 $\mathrm{Na}^{+}$チャネルについて解説した が，構造と機能の詳細については不明の点が少な くない，近年の特筆すべき遺伝子技術の進歩とし て, $\mathrm{Na}^{+}$チャネル mRNA をアフリカツメガエ ル卵母細胞に注入して発現させ，膜電位固定法な ごで $\mathrm{Na}^{+}$チャネルの機能を測定できるように なったことが挙げられる (Fig. 10).この方法を 応用し, 遺伝子の特定部位を変異させた $\mathrm{Na}^{+}$チャ ネルの機能を調べることにより, センサー, ゲー ト,フィルターなどの機構とそれらの機能を担う ドメインの関係の詳細な解明が期待される.

\section{5. おわりに}

生体膜におけるイオンチャネルは蛋白分子から 成り, 内部には透過イオン種を選択するフィル ター部とチャネルの開閉を司るゲート機構が備 わっている. 上記の条件を満たす輸送システムを 人工膜に作成することが可能であろうか，その場 合, どのような素材の人工膜によ゙のような素材の チャネルを組み込む必要があるだろうか. 生体膜 イオンチャネルの仕組みの解明は, 種々の目的の 人工膜イオンチャネルの作成に有益な情報をもた らすと思われる. 一方, 種々の人工膜イオンチャ ネルの透過性の検討は, 生体膜におけるイオン輸 送の機構解明之理論解析に役立つ之思われる.

\section{文献}

1) S. R. Goodman, "Medical Cell Biology", J. B. Lippincott Company, Philadelphia (1994)

2) 二井将光, “生体膜工学”, 丸善, 東京 (1991)

3) A. L. Lehninger, "Principle of Biochemistry", Worth Publishers, New York (1993)

4) 本郷理憲, 広重 力, 豊田順一, 熊田 衛, “標準 生理学”, 医学書院, 東京 (1990)

5）宇井理生, 香川靖雄, 春日雅人, 野澤義則, “生体 膜一新しい膜学への招待”, 講談社, 東京 (1995)

6) M. Noda, T. Shimizu, T. Tanabe et.al. $\mathrm{Na}^{-}$ ture, 312, 121 (1984)

7) W. A. Catterall Physiol. Rev. 72, S15-48 (1992)

（受付 1995 年 9 月 25 日） 